\title{
O SUJEITO LEITOR, ESSE ENIGMA: INVESTIGANDO A RECEPÇÃO DO TEXTO LITERÁRIO NA ESCOLA
}

\section{THE READER-SUBJECT, THIS ENIGMA: INVESTIGANTING THE RECEPTION OF LITERARY TEXTS AT SCHOOL}

\section{Raquel Cristina de Souza e Souza ${ }^{1}$}

Resumo: A partir da contribuição teórica de Michel Picard (1986) e Vincent Jouve (1992), pretendemos analisar os diários de leitura de três turmas de sétimo ano de uma escola federal de educação básica, nos quais os estudantes registraram sua recepção das obras Édipo, o maldito (reconto de Marie-Thérèse Davidson) e $O$ cão dos Baskervilles (de Conan Doyle). Nosso objetivo é encontrar pistas sobre a formação do leitor literário na escola, tendo como premissa o papel da subjetividade no processo de elaboração semântica que ocorre durante a leitura, o qual exige permanente ação (meta) cognitiva e afetiva. Do leitor implícito, inscrito na obra e assimilado pelo leitor especialista, chegamos ao leitor implicado, cuja contribuição pessoal afeta o texto, ao mesmo tempo em que é afetado por ele.

Palavras-chave: diário de leitura; ensino fundamental; leitura subjetiva; recepção.

Abstract: Based on the theoretical contribution of Michel Picard (1986) and Vincent Jouve (1992), we intend to analyze the reading journals of three seventh grade classes of a public Middle School, on which the students registered their reception of the works Oedipus, the damned (retelling by Marie-Thérèse Davidson) and The hound of the Baskervilles (by Conan Doyle). Our goal is to find clues about the development of the literary reader in school, having as premise the role of subjectivity in the semantic elaboration process that occurs during reading, which requires permanent (meta) cognitive and affective action. From the implied reader, inscribed in the work and assimilated by the expert reader, we come to the implicated reader, whose personal contribution affects the text while being affected by it.

Keywords: reading journal; middle school; subjective reading; reception.

\section{Introdução}

No final da década de 60, o campo dos estudos literários assistiu à emergência de um conjunto de tendências teóricas que se interessavam pela valorização do receptor da obra e passaram a propor abordagens do texto literário que contrariavam aquelas que haviam dominado os debates até então, segundo o percurso resumido por Antoine Compagnon (2001): a obra como expressão da psicologia do autor (abordagem expressiva); a obra como reflexo do mundo exterior (abordagem mimética); e a obra como objeto autônomo e

\footnotetext{
${ }^{1}$ Doutora em Letras Vernáculas (Literatura Brasileira) pela Universidade Federal do Rio de Janeiro. Professora do Ensino Básico, Técnico e Tecnológico do Colégio Pedro II, campus Realengo II. E-mail: raquelcsm@gmail.com
} 
autossuficiente (abordagem formalista). É particularmente em reação aos métodos imanentes desta última, representada pelo Estruturalismo francês e o New Criticism norte-americano, que surge um conjunto de abordagens pragmáticas, preocupadas com a relação entre a obra e o público, ou seja, entre os signos e seus usuários - seguindo, aliás, uma tendência generalizada em todo o campo da linguagem à época. Dentre elas, destacam-se a Teoria do Efeito e a Estética da Recepção.

No mundo francófono, desde a década de 80, importantes contrapontos têm sido feitos ao caráter virtual que o leitor adquiriu nessas reflexões. Em oposição ao leitor implícito de Iser, e pretendendo avançar no modelo teórico do leitor coletivo de Jauss, Picard (1986) deseja incluir o leitor real na sua investigação, retirando a recepção do campo da mera proposição. O autor fala em um "inconsciente do texto" e tenta apreendê-lo por meio do arcabouço teórico da psicanálise, com destaque para Winnicott, além de Freud, almejando demonstrar que a leitura literária coloca em jogo e reforça, no leitor, os mecanismos de defesa psíquica, como a sublimação, que são vitais para o equilíbrio do indivíduo. Entretanto, o modelo de Picard continua tão abstrato quanto o de Iser, na medida em que nenhuma leitura efetivamente empírica - a não ser a do próprio Picard, leitor ideal - é verificada. Seu trabalho, portanto, acaba por responder negativamente, à sua revelia, à indagação de Compagnon (2001) sobre a possibilidade de a leitura real constituir objeto teórico.

Ainda assim, sua crítica teve como primeiro desdobramento importante arejar e movimentar o campo pedagógico em torno de uma reflexão mais sistemática e teoricamente interessada em torno da formação do leitor literário; o segundo desdobramento pode ser verificado no salto em direção à teorização do leitor real a partir das concepções de leitura subjetiva e sujeito leitor, hoje centrais no debate acadêmico sobre a formação do leitor no contexto francófono e presentes nos documentos oficiais que orientam a prática nas escolas dos países em questão. A principal contribuição dessas pesquisas recentes é ter efetivamente levado a cabo a investigação dos processos de leitura a partir do testemunho de leitores, como preconizava a Estética da Recepção. Diários de leitura e autobiografias de leitores têm sido os principais instrumentos de registro e fonte de análise do arenoso terreno da recepção dos textos literários. Mesmo assumindo o caráter restrito e instável de acesso à subjetividade leitora por meio desses dispositivos, os pesquisadores apostam no seu potencial para observar a existência de uma relação pessoal com os textos e de traços do processo de elaboração identitária, além de constituírem meios privilegiados de observação do processamento 
cognitivo e afetivo da leitura, desde a lógica associativa que lhe é própria (memória pessoal e memória textual), até a singularização do texto e sua apropriação pessoal, o que ajuda a compreender como se constrói a identidade de leitor.

\section{Os impasses do sujeito leitor na escola}

Uma questão recorrente na produção acadêmica acerca da leitura subjetiva na escola diz respeito à relação tensa entre a leitura literária como prática social e como prática escolar e, consequentemente, sobre as implicações de inserir as singularizações de leitura na sala de aula. É possível, ou desejável, que se leia na escola como se lê fora dela? Investir na subjetividade dos estudantes significa renunciar à didatização e à sistematização? Faz sentido deslocar a posição monológica e autoritária da leitura prevista pelo professor e ainda assim manter sua autoridade na posição de mediador?

Daunay (1999) observou como a bibliografia sobre a leitura literária (inclusive a obra de Picard) tem sido marcada por uma hierarquização que, sob diferentes nomenclaturas, opõe leitores estéticos (o leitor especializado) a leitores semânticos (o leitor não especializado), sendo aqueles caracterizados por um distanciamento crítico valorizado em detrimento de uma prática leitora marcada pela adesão pessoal ao texto. Via de regra, o leitor estético seria aquele que não cai nas armadilhas da ilusão referencial e atribui valor aos aspectos formais das obras.

Mais produtivas são as perspectivas recentes, aqui representadas por Dufays (2013), que compreendem toda leitura como um processo dialético que se caracteriza por duplos movimentos de aproximação afetiva e afastamento crítico; de apelo à emoção e à razão; de análise sistemática e imersão no mundo fabulado. Mais do que uma oscilação entre dois polos opostos de recepção, tais posturas estariam localizadas em um continuum. O vai e vem dialético significa que no curso da leitura o leitor mobiliza um feixe de competências ora ancoradas na ilusão referencial, ora na reflexão crítica, que se sobrepõem e se retroalimentam.

Sendo assim, parece problemático, como destaca o autor, limitar o trabalho em sala de aula a um ou outro polo, seja porque a concepção analítico-textual ignora o papel funcional da subjetividade leitora, seja porque a leitura pessoal, sem um trabalho de construção e partilha de sentidos, encerra os estudantes em suas próprias referências e embota o processo de aprendizagem. Isso é particularmente importante quando pensamos no contexto brasileiro, marcado por uma profunda desigualdade na distribuição de bens simbólicos (mesmo os não legitimados). Uma questão que precisa ser levantada, portanto, é em que medida a ênfase da 
escola em uma perspectiva que valoriza o projeto de dizer marcado textualmente, mas que não acolhe a recepção singularizada, em contextos onde a imersão afetiva no mundo letrado não ocorreu ou ocorreu de maneira acidentada antes da escolarização formal, contribui para nosso fracasso na empreitada de formar leitores.

Concordamos com Dufays (2013) que a leitura dialética deve ser vista como uma atividade a se promover na escola, e não como uma competência já adquirida e pressuposta. Trata-se de criar oportunidades para que a leitura literária seja de fato experimentada pelos estudantes, em seu movimento de aproximação e afastamento, e não se torne objeto de uma prática de reprodução da leitura do professor ou do material didático, que não faz avançar as competências dos alunos e dificulta a adesão subjetiva aos textos. Por seu caráter integrador, essa perspectiva favorece uma prática didática mais equilibrada entre o leitor implícito, inscrito na obra, e o sujeito leitor, que se movimenta livremente pelo texto, escapando assim do assédio tanto da leitura normativa e monológica, quanto da ausência de sistematização e avaliação, aspectos incontornáveis da escolarização.

\section{Do leitor implícito ao leitor implicado}

Apesar da crítica que possamos fazer às contradições de Picard, o fato é que seu modelo teórico sobre a leitura literária oferece um caminho analítico muito profícuo, desde que não caiamos na armadilha da hierarquização e pensemos sua sistematização à luz do vai e vem dialético de Dufays. Sua concepção triádica do leitor, assim como sua revisão feita por Jouve (1992), servirão de grade analítica para pensarmos a dinâmica do afastamento e aproximação na leitura literária, reabilitando o dispositivo da identificação como central na leitura de ficção e o investimento subjetivo como propulsor do processo de elaboração semântica empreendido pelo leitor.

Com o objetivo de encontrar sinais do vai e vem dialético (e suas implicações) na recepção leitora dos estudantes do sétimo ano do ensino fundamental de uma instituição federal de educação básica, recolhemos exemplos dos diários de leitura elaborados para as obras Édipo, o maldito, reconto de Marie-Thérèse Davidson e tradução de Heitor Ferraz Mello, e $O$ cão dos Baskervilles, de Conan Doyle, traduzido por Antonio Carlos Vilela. O gênero previsto no conteúdo programático para o trimestre era a narrativa policial e o reconto da tragédia grega teve seus primeiros capítulos suprimidos para que se tornasse uma narrativa de investigação. As obras foram escolhidas com base em diferentes critérios: legibilidade 
(relação entre competências desenvolvidas e a desenvolver), qualidade estética, possibilidade de leitura intertextual, potencial de identificação e de expansão das referências literárias.

A dinâmica de trabalho já era bem conhecida das três turmas, com quem trabalhávamos desde o ano anterior. Semanalmente, os estudantes leem um número de páginas/ capítulos previamente determinado registrando sua conversa nas margens do texto. Tal conversa é estimulada a partir de algumas orientações: dúvidas (eixo do automonitoramento da compreensão), reações (eixo das emoções), concordâncias e discordâncias (eixo axiológico) e conexões (eixo das experiências pessoais e da rede intertextual). Aos poucos, os alunos vão encontrando formas singulares de fazer esse registro, usando legendas, emojis, cores e post its. Também semanalmente esse diálogo à margem do texto é o ponto de partida para a sessão de conversa literária (BAJOUR, 2012) que acontece em uma sala de aula preparada para este fim: carteiras em semicírculo, tapetes e almofadas no chão. As leituras individuais vão sendo assim aprofundadas e diversificadas a partir da discussão, que tem a professora como uma orquestradora de vozes e uma guia experimentada que motiva, organiza, orienta, revela, enfatiza, problematiza, modaliza, provoca - a depender do acontece em cada encontro, com cada turma. No final do processo, que dura entre um mês e um mês e meio, os estudantes devem transformar suas anotações em um texto pessoal, que inclui suas anotações da leitura individual e das contribuições coletivas. Eles também devem registrar sua relação com os textos a partir de atividades criativas cujo objetivo é interferir na obra original, radicalizando a premissa de que cada leitor procede a uma concretização singular da obra literária ao reconfigurar o texto a partir de seu arcabouço de experiências anteriores de leituras e vivências. A essa reconfiguração Gérard Langlade (2008) chama "atividade ficcionalizante do leitor", quer dizer, a resposta do seu imaginário às solicitações da obra, desde a instauração da coerência mínima do texto (estabelecimento de relações causais, visualização de cenas e ambientes, julgamento moral dos personagens) até a alteração do texto por meio de supressões, transformações e acréscimos.

Tanto os relatos pessoais produzidos pelos alunos, quanto as reficcionalizações empreendidas serviram de material para investigarmos a presença do sujeito leitor na sala de aula em um contexto de estímulo a uma prática dialética que nasce das leituras singulares e a elas retornam, depois de um intenso trabalho de construção coletiva. Nosso objetivo foi, portanto, buscar pistas sobre o processamento da leitura literária a fim de refletir sobre as implicações de uma abordagem que nos tira da zona de conforto do leitor modelo, que 
silencia o leitor real e não polemiza diferentes interpretações. Essa investigação nos exigiu, entretanto, a reformulação do quadro teórico inicial, já que a observação do comportamento real dos leitores colocou à prova a sistematização dos autores. Assim, chegamos a cinco categorias, que serão melhor delineadas nas seções abaixo. As quatro primeiras (ledor, lido, leitante jogador e leitante intérprete $)^{2}$ são caudatárias das reflexões de Picard e Jouve, mas a quinta (metaleitor) foi criada pela necessidade imposta pela análise.

\subsection{O ledor (liseur) - $O$ corpo que lê}

O ledor corresponde à dimensão do ato físico de ler, à relação do leitor com a materialidade do livro (tamanho, formato, volume, cheiro, cor) e com a situação de leitura (onde, quando e como). É a instância que mantém o leitor no plano do real, "com os pés no chão", como diz Picard (1986) e o livro nas mãos. Corpo, tempo e espaço são realidades concretas que funcionam como um enquadramento que delimita as experiências extra e intratextuais, mas que não são assim sentidas pelo ledor, que se abandona à vivência vicária do texto sem perceber a interferência do exterior no processo.

Jouve (1992) desconsidera a categoria do ledor por entendê-la pouco operacional para as análises textuais que pretende fazer. No nosso caso, entretanto, as questões relacionadas à materialidade são imprescindíveis para pensar a recepção e a formação do leitor, tendo em vista o papel decisivo que a convivência com o objeto livro desempenha no itinerário leitor dos indivíduos. Hoje sabemos como crianças que manipulam livros desde cedo já chegam à escola, antes da alfabetização, familiarizadas com protocolos de leitura, o que as colocam em vantagem em relação às crianças que nunca manusearam livros e não fizeram deles objeto de afeto que atravessam suas relações sociais. Além disso, ilustrações, cores e formas servem de andaimes importantes para a construção de sentidos e igualmente preparam as crianças para a atividade inferencial e relacional que é a leitura, sobretudo em uma época tão marcada pelo regime visual de apreensão da realidade e que tem feito do investimento gráfico e material critério de qualidade estética e isca para o leitor contemporâneo, além de diferencial para competir no mercado. Sabemos também como a presença física do livro e os eventos de letramento estão estritamente relacionados a uma memória afetiva da leitura, que interfere de maneira decisiva na construção de identidades leitoras.

\footnotetext{
${ }^{2}$ Utilizamos parcialmente a tradução de Jouve (2002) por Brigitte Hervot, que é a mesma presente na tradução de Helaine Giraldeli Balla do texto de Anne Vibert (2014).
} 
Nos diários de leitura das crianças, o ledor é a dimensão que menos aparece. Atribuímos isso à sua própria invibilização durante a leitura, fruto da naturalização do ato físico de ler e da imersão no mundo fabulado, que "desliga" o leitor do mudo exterior; entretanto, não podemos deixar de dizer que essa quase ausência também pode ter a ver com a própria exclusão do corpo da escola. A forma como o espaço de aprendizagem é concebido, limitado pelas salas e pelas carteiras enfileiradas, onde os estudantes passam horas sentados, bem como a própria aprendizagem, descarnada, unilateral e passiva, podem ser fatores que contribuem para essa não percepção por parte dos alunos da atividade leitora como uma prática apenas mental. Nos exemplos abaixo, podemos perceber como o ledor se manifesta e interfere no processo de leitura, favorecendo ou dificultando a adesão ao mundo ficcional:

\begin{abstract}
A minha leitura do livro Édipo foi mais prazerosa do que eu imaginei, pois eu havia me acostumado a ler apenas em livros, que possuem capas, sendo assim, eu tenho preguiça de arrumar uma posição para ler, isso quando achava um suporte qualquer (mesa, braço de sofá etc...) para o livro, (já que não gostava de segurá-lo e o deixava ali a página virava sozinha. Mas ao achar a posição perfeita para ler, vinha o sono, isso tudo porque pretendia ler e anotar os destaques ao mesmo tempo, que foi o que eu fiz na primeira parte. Porém, na segunda e última parte do livro, fui lendo e anotando para não dar sono e ignorando a vontade de não querer segurar a folha $\mathrm{e}$ um livro qualquer. ${ }^{3}$ (Diário do leitor D.A)
\end{abstract}

Eu estava senda no sofá, lendo o livro, quando passou na TV, canal HH, history... o programa chamado pântano ele é muito parecido com o livro fala de um pântano que é amaldiçoado por uma criatura com formato de um cachorro. (Diário da leitora La.)

Não estava com vontade de ler Sherlock por causa da edição dela, é muito ruim, desculpa. (Diário da Leitora M.E.S.)

No primeiro excerto o leitor se refere ao fato de o reconto de Édipo (sem os capítulos iniciais) ter sido disponibilizado em fotocópia, o que alterou sua relação física e afetiva com o texto pelo apagamento das marcas gráficas e descaracterização do objeto. No segundo, chama atenção que a leitura estivesse sendo feita com a televisão ligada, o que desperta o alerta sobre as transformações pelas quais a capacidade de concentração necessária à leitura tem passado nas gerações mais novas, imersas em contextos multitarefas. $\mathrm{O}$ excerto mostra que as atividades concomitantes, nesse caso específico, levaram a leitora a exercitar a habilidade de comparar textos diferentes e construir uma rede intertextual e intersemiótica a partir da narrativa de Conan Doyle. No último exemplo, a leitora atribui à fonte pequena da tipografia e à falta de espaçamento (como ela esclareceu oralmente) as causas pelo seu desinteresse, tornando relevantes aspectos que podem passar despercebidos ao professor.

\footnotetext{
${ }^{3}$ Alteramos apenas a ortografia/ acentuação dos exemplos para facilitar a leitura. Pontuação e estrutura originais foram mantidas.
} 
Nas imagens abaixo, é interessante observar como o uso material do diário, como objeto pessoal de registro, revela ou duplica a relação física com a leitura:

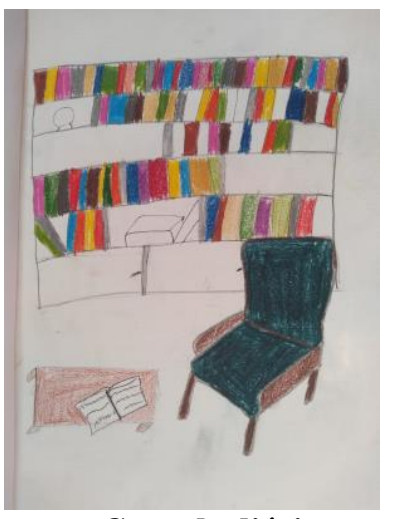

Capa de diário Diário da leitora J.

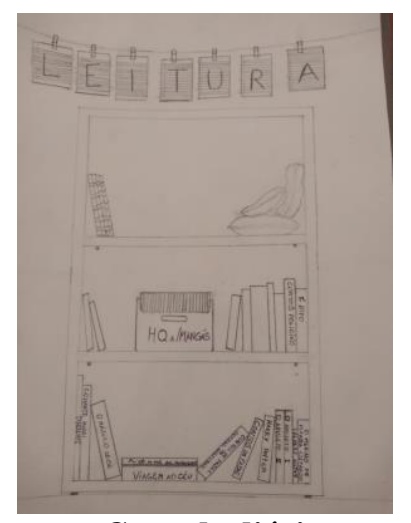

Capa de diário Diário do leitor D.A.

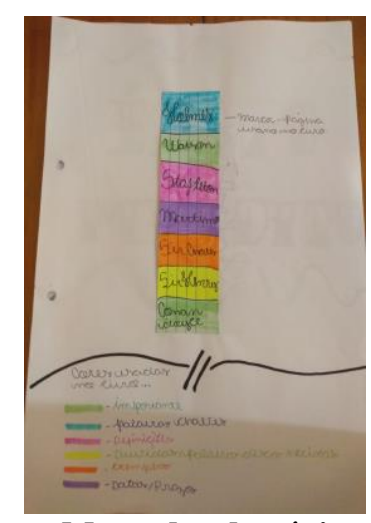

Marcador de página Diário do leitor D.M.

Em duas das imagens, que correspondem a capas elaboradas para os diários, os leitores retratam ambientes de leitura. A primeira remete a um local existente ou imaginado, mas ideal e confortável, onde a leitura é atividade exclusiva; já a segunda é claramente a reprodução da estante de livros que existe na sala de aula, onde podemos encontrar as leituras obrigatórias do ano anterior (Comandante Hussi, $O$ mágico de $\mathrm{Oz}$ ) e leituras do circuito livre (Alice no País das Maravilhas, Viagem ao céu, Harry Potter, O menino do pijama listrado), além de HQs, mangás e das almofadas que usamos durante as conversas literárias. O registro é interessante por demonstrar a relação afetiva com a sala de aula como espaço privilegiado de leitura e por dar pistas da construção da biblioteca interior do aluno, ou seja, de como a cultura literária institucionalizada interfere nos itinerários singulares de leitura e é apropriada para além dos muros da escola (VIBERT, 2014). O terceiro exemplo mostra a relação física e afetiva do leitor com o livro a partir da elaboração de um marcador de página feito com os nomes dos personagens por iniciativa própria do aluno. Logo abaixo, vemos a legenda criada (“importante”, "palavras-chave”, “dúvidas" “exemplos”), também por iniciativa própria, para orientar seu diálogo com o texto nas margens das páginas, esta sim uma interferência material deliberadamente estimulada com vias a promover a aproximação ao texto e a apropriação do processo de leitura.

\subsection{O lido $(l u)$ - O inconsciente que lê}

A forma passiva do verbo é a pista para compreender essa categoria postulada por Picard (1986) como aquela que nomeia a instância leitora que se abandona às emoções, às 
identificações e à atividade fantasmática. Remete ao inconsciente do leitor, que satisfaz suas pulsões por meio de determinadas cenas e nelas reencontra imagens de seus próprios fantasmas; é o leitor, em última instância, que é "lido" pelo texto e confrontado com o que antes estava nas sombras, podendo ou não fazer da interação com a obra um meio de decifrar a própria existência e reelaborar sua identidade.

Estamos, portanto, no campo da identificação, mecanismo principal de adesão do leitor ao texto literário e que costuma ser considerada equivocadamente como marca de uma leitura ingênua e acrítica. Na verdade, não é possível ler literariamente sem imersão no mundo fabulado e sem a suspensão voluntária da descrença. São os personagens que mobilizam a atenção do leitor e guiam a leitura no plano do "como se", configurando-se como liames entre realidade e ficção (JOUVE, 1992). O lido é capturado pelo jogo, ficando sujeito ao efeito de real e permitindo-se viver por procuração uma série de situações por meio da ilusão de estar diante de uma pessoa evoluindo em um mundo do qual ele mesmo participa durante a leitura.

Jouve (1992) desdobra essa categoria entre o lido (responsável pelo investimento pulsional, aquele que reage passivamente ao personagem com um álibi fantasmático e suporte de sua ação inconsciente) e o lendo (responsável pelo investimento afetivo, aquele que reage ativamente ao personagem como objeto de sua simpatia ou antipatia). Este seria a parte de nós que responde ao texto física e afetivamente, chorando, rindo, angustiando-se, revoltando-se. No escopo deste trabalho, esta diferenciação não nos é útil. Primeiro, porque nos faltam instrumentos de análise e fundamentação teórica para explicar à luz da psicanálise as relações latentes entre os registros dos alunos e seu inconsciente. Em segundo lugar, porque não vemos diferença significativa entre as duas categorias, dado que a reação afetiva e a resposta axiológica ao mundo fabulado já nos parecem manifestações dessa vida interior precariamente apreensível. Preferimos assim operar com a categoria da simbolização (PETIT, 2013), ou seja, enxergar os personagens e cenas como metáforas para condutas, aspirações, reações reveladas aos sujeitos leitores, confrontando-os com a alteridade.

Nas reficcionalizações dos alunos, podemos perceber os movimentos de construção da coerência mimética das obras, seja por estratégias de ordenação dos eventos, seja pelo preenchimento de lacunas do texto pelo imaginário do leitor. Cada escolha é claramente guiada por uma necessidade de organizar informações para atribuir sentido ao mundo representado, como é o caso da linha do tempo e da árvore genealógica para $O$ cão dos Baskervilles (narrativa intricada do ponto de vista dos eventos e da proliferação de 
personagens como estratégias de enredamento na trama) e do mapa para a fuga de Édipo de Corinto a Tebas, já que esse deslocamento é fio principal do enredo, a partir do qual as leituras simbólicas serão sobrepostas:

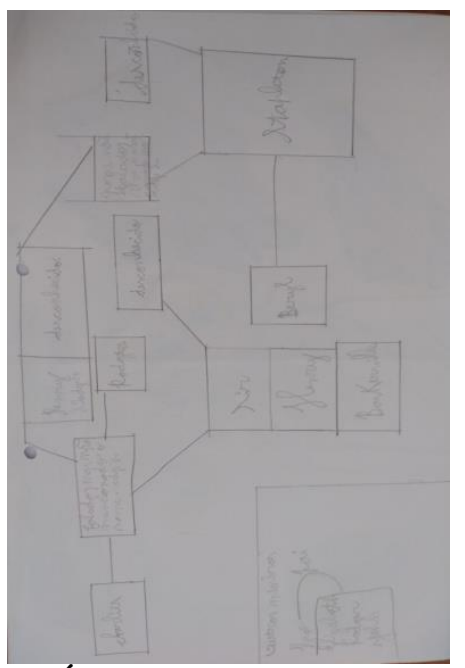

Árvore genealógica

Diário do leitor $\mathbf{T}$.

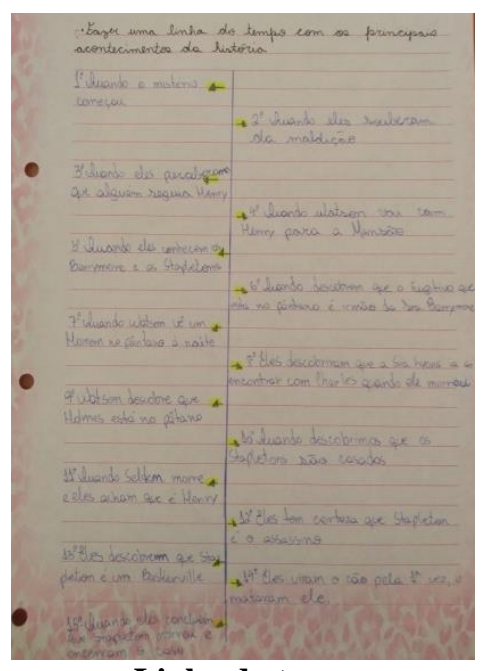

Linha do tempo

Diário da leitora M.E.P.

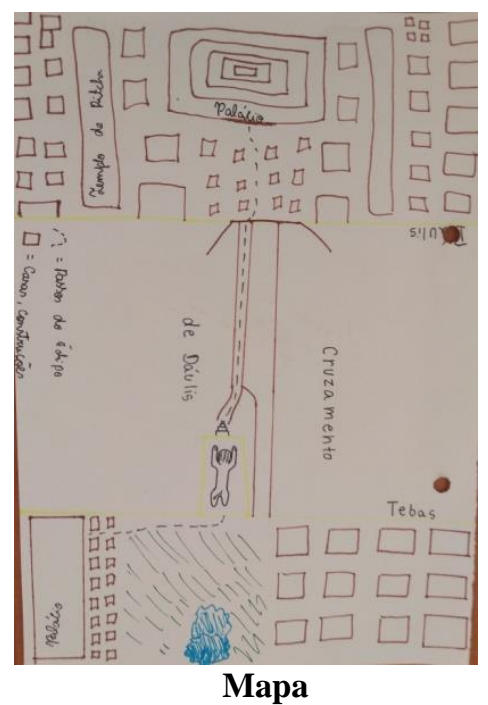

Diário da leitora $B$.

As ilustrações de personagens, cenas e ambientes são recursos para concretizar a produção de imagens mentais durante a leitura, mecanismo essencial para construção do efeito de real. Na primeira imagem, o retrato de Sherlock Holmes dialoga com referências visuais já presentes no imaginário do leitor a partir de seu contato com a cultura de massa. $\mathrm{Na}$ segunda e terceira imagens, percebemos o uso de cores e outros recursos de forma expressiva. Na cena final de Édipo, o rei e sua filha Antígona estão envoltos em uma luz azul que revela um elemento de fixação da sensibilidade da leitora, explicitada no diário, de que tinha se emocionado com a relação dos dois por se identificar com Antígona. Na ilustração do pântano, que é pano de fundo da narrativa de Conan Doyle, a leitora tenta reproduzir a atmosfera lúgubre das descrições e seu efeito de medo e suspense:

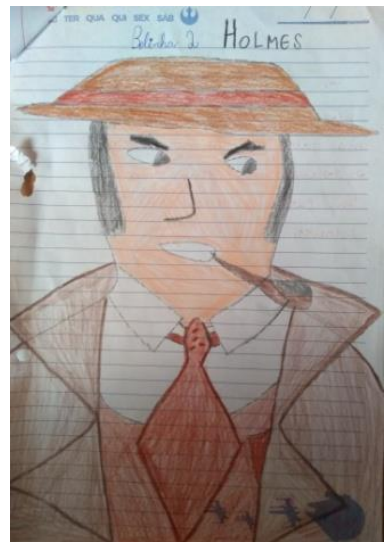

Ilustração de personagem

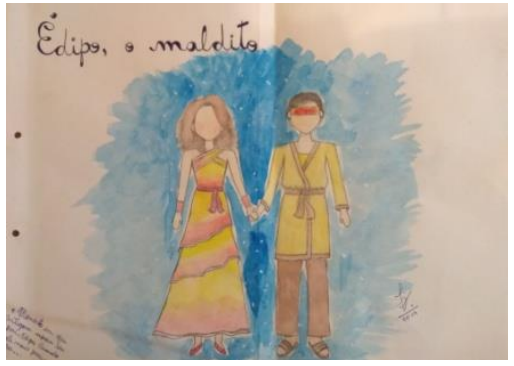

Ilustração de cena

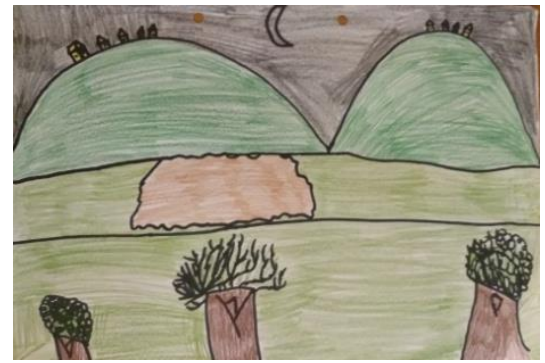

Ilustração de ambiente 
Diário do leitor A.

Diário da leitora $\mathbf{L}$.

Diário da leitora $\mathbf{E}$.

A criação de poemas também foi recorrente como meio de recuperar o fio narrativo dos textos e os nexos causais e explicativos entre os eventos, além de serem mostras de apropriações pessoais e criativas dos textos. No primeiro exemplo abaixo, o leitor faz de Édipo eu lírico para se colocar no lugar do personagem e ressaltar seu incômodo com o sentimento de impotência diante do destino; no segundo, que de acordo com o leitor é uma música, o reconto serve de pretexto para a expressão de sua reação emotiva, que ele também pretende provocar no seu leitor:

\begin{tabular}{|l|l|}
\hline Poema 1 & Poema 2 \\
\hline $\begin{array}{l}\text { Desde antes do meu nascimento } \\
\text { Um oráculo viu meu futuro } \\
\text { Onde a morte e o incesto } \\
\text { Mudariam o meu rumo }\end{array}$ & Morte, dor \\
& Pavor, horror \\
Isso tem aqui \\
Não importa o quanto correr \\
Nem quantos enigmas decifrar & Essa história não foi feita \\
Nem quantas pestes curar & Para criança \\
No final, irei sempre sofrer & Dormir \\
& Mura Ra Ra Ra \\
Quando tudo se concretizar & O olho ele vai furar \\
Meu pai, morto irá estar & Mura Ra Ra Ra \\
Minha mãe se suicidará & Lágrimas de sangue \\
E eu, pararei de enxergar & Vai chorar \\
(Diário do Leitor M.) & \\
\hline
\end{tabular}

A cena em que Édipo fura os próprios olhos, presente nos dois textos acima, foi responsável pela maior parte da das manifestações de envolvimento afetivo com o texto, como podemos perceber na recorrência com que esta cena foi retratada visualmente:

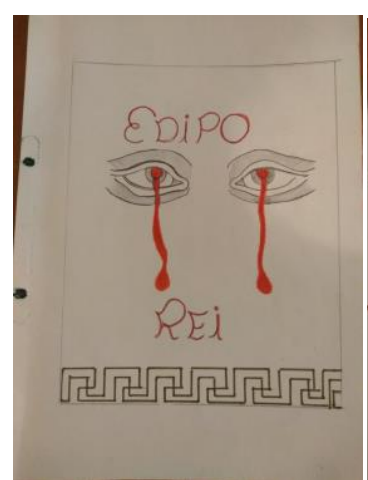

Ilustração de cena

Diário do leitor $\mathbf{G}$.

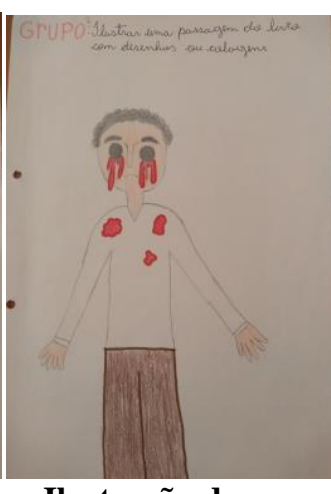

Ilustração de cena Diário da leitora I.

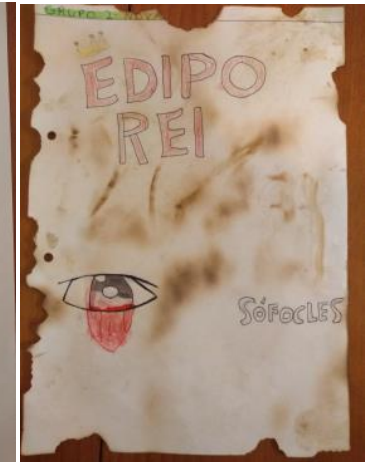

Ilustração de cena Diário da leitora Ju.

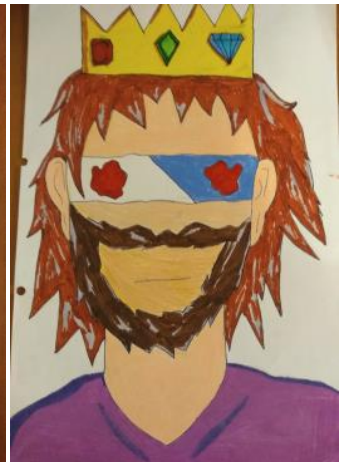

Ilustração de cena

Diário do leitor $\mathbf{P}$. 
Os alunos demonstram suas emoções por meio de adjetivos e substantivos abstratos, algumas vezes inventados ("escandalosa", "envolvente", “enojado", "triste, "horrorizante", “emocionantíssimo", "sensação de alívio", "angústia") e verbos que tentam dar conta também de reações físicas ("chorei”, "me assustei”). O desconforto com a leitura ora é sentido como negativo ("No final da história de Édipo eu achei um final muito triste, mas feliz ao mesmo (...) porque acabou finalmente essa história depressiva, que me deixou muito abalada. - Diário da leitora I.), ora é justamente o motor da adesão, mesmo diante da impossibilidade de verbalizar sua recepção ("Depois desse livro eu até hoje estou incomodado e eu não sei por quê, eu acho que esse livro me tocou mais que todos os outros que eu já li sozinho, eu vou procurar outros livros tristes agora." - Diário do leitor G.). Outro aluno diz ter ficado horrorizado "mesmo já sabendo o que iria ocorrer" (Diário do leitor W.L.), o que é uma pista interessante para pensar que a produção dos efeitos é de fato resultado de estratégias textuais, e não uma mera resposta ao tema. Alguns alunos procuram elaborar mais a verbalização de sua recepção emotiva, atrelando-a diretamente a excertos do texto, o que reforça o papel da relação forma/ efeito e ainda é revelador da importância que os fragmentos têm ao iluminarem aspectos da vida interior dos leitores:

\begin{abstract}
Durante a leitura destaquei vários trechos que me transmitiam sentimento e sensações, como por exemplo quando Jocasta se matou. Ela era tão doce, tão amorosa com os filhos e seu esposo. Eu adorei o jeito sensível dela, assim que apareceu na história. Fiquei bastante abalada quando ela se enforcou, não consigo imaginar sua família sem ela. Outro trecho que me tocou muito, foi o da página quarenta e três, que diz assim: "Numerosos são aqueles que contam, entre as jovens vítimas da esfinge, um filho ou um irmão". A morte é algo que não consigo suportar. (Diário da leitora M.L.)
\end{abstract}

Outro leitor explica com suas próprias palavras o mesmo que Petit (2013) acerca da importância dos fragmentos. Ele diz querer "citar, repassar, copiar e levar para o resto da vida" "as partes simbólicas" (Diário do leitor D.M.) que o ajudaram a fazer descobertas sobre o texto e sobre si.

O texto vai servindo de caixa de ressonância para as experiências e reflexões dos leitores e oferece-lhes metáforas, por meio dos personagens e eventos, para nomear e simbolizar o que pensam e sentem. Foi o que aconteceu com a leitora no exemplo anterior, obrigada a enfrentar a morte ficcionalmente e experimentar a contradição da catarse, que é afinal a grande contradição da leitura de ficção: ela vive a dor da morte de Jocasta, mas ao 
mesmo tempo percebemos seu alívio com a distância que separa os mundos intra e extratextuais. O processo se repete em outros leitores, de diferentes formas, revelando seleções subjetivas de determinados aspectos das narrativas que lhes permitem enunciar a si mesmos pelas palavras do outro. No primeiro exemplo abaixo, o medo do abandono é revelado pelo abandono de Édipo, duplicado em sua vivência imediata; no segundo, a desidentificação com o personagem ilumina um processo de autoconhecimento:

Eu tenho uma vizinha que tem 12 anos, o nome dela é A., ela tem um irmão que tem 9 anos, e eles são adotados desde bebês, eu fico me pondo no lugar dela, deve ser muito ruim saber que não foi criada pelos pais verdadeiros. (Diário da leitora I.)

Do início ao fim da leitura, percebemos uma coisa: não temos controle total da nossa vida. Às vezes as coisas não saem como nós queremos. Outra coisa que eu reavaliei foi sobre mim. Eu deveria ser como Jocasta, calma, doce, apaziguadora, controladora de seus sentimentos. Acho que sou muito agitada, impaciente, às vezes rude, descontrolada. Deveria tentar ser mais calma e paciente. (Diário da leitora L.)

Nas inúmeras entrevistas que os alunos fizeram com os personagens, é possível entrever, por um lado, sua imersão no mundo fabulado, ao tomarem os seres ficcionais como reais; por outro, as perguntas que lhes são dirigidas são ilustrativas do processamento da leitura no nível da linearidade do enredo e de seu encadeamento causal. Perguntas como: "Tirésias, quando a sua deficiência física começou?"- Diário da leitora La.); “Seus filhos vão brigar pelo trono?” - Diário da leitora A.B.; "Não há outra explicação para onde foi o Stapleton ao invés de ter morrido?" - Diário da leitora M.E.T.); são exemplares da ação leitora no nível da progressão narrativa e da coerência mimética motivada por vazios e indeterminações da estrutura de apelo do texto. Mas as perguntas apontam ainda para a ação dos esquemas axiológicos dos leitores na construção dos sentidos. A seguir, reproduzimos questionamentos reveladores do interesse dos leitores pela persona dos personagens e pelas implicações de suas atitudes (que na verdade dizem respeito ao seu próprio conjunto de valores, incômodos e sensibilidade). Eventualmente a entrevista é respondida pelos próprios leitores no lugar dos personagens, incorporando seu discurso e explicitando a superposição de realidade (leitor) e ficção (personagem) - esta dando pistas sobre aquela:

Você furou os olhos porque iria torturar o assassino?

Como você se sente após ficar cego?

Você reconhece que Creonte estava certo?

Quando você soube que tinha casado com sua mãe, o que você pensou?

Como filhos reagiram à notícia de que a mãe era avó?

Creonte inda confia em você? (Diário da leitora A.B.)

Você queria ter a oportunidade de ter relação com seus pais biológicos?

Sim, mas infelizmente tudo aconteceu pra que que chegasse até aqui! 
Como você se sente agora?

Sinto apesar de tudo que o destino me traria aqui, mas agora penso que devo levar minha vida mais leve e aproveitar quem está ao meu lado.

Se sente orgulhoso por ter matado a Esfinge?

Sinto sim, pois libertei o povo depois de muito tempo, mas nos próximos anos me tornei metido e não gosto disso hoje em dia.

Sente saudades de seus filhos?

Muita, espero que eles me tenham como reflexo para não se arrependerem no final.

(Diário da leitora M.A.)

Como você vê Édipo, o maldito ou rei?

O maldito, por causa da grosseria e arrogância dele. (Dário da leitora La.)

A Sra. Stapleton deveria ser presa?

Não! Que absurdo! Ela foi usada, manipulada e agredida por Stapletonn e por estar cheia de amor por ele não viu o monstro que era.

$\mathrm{O}$ que você acha de Watson como seu assistente?

Não conte a ele, mas o considero um homem bom, puro, e inteligente (não mais que eu), óbvio. (Diário a leitora M.E.T.)

[Jocasta,] Se encontrasse Édipo agora, o que falaria?

Primeiramente me desculpar por ter o abandonado entre os animais selvagens, que fui uma péssima mãe. Segundamente, "fique longe de mim!” Não quero nunca mais vê-lo. Estou envergonhada. (Diário da leitora Ju.)

Por fim, há uma profusão de cartas e autobiografias ficcionais escritas pelos alunos, nas quais chama atenção a escolha recorrente por personagens absolutamente secundários, como Eurinome (a criada de Édipo) e a Sra. Barrymore (governanta na mansão dos Baskervilles). Aliás, esta seleção marginal é muito reveladora da apropriação pessoal dos textos. No caso de Eurinome, a autobiografia destaca seu papel de coadjuvante na narrativa e expectadora da vida, de certa forma apontando para a própria leitora, ela mesma extremamente tímida e pouco participativa nas aulas, apesar de dialogar intensamente com os livros lidos no seu diário. Já no caso da Sra. Barrymore, a carta escrita para confortá-la da morte do irmão foi um pretexto para a leitora expressar sua própria visão sobre a morte. A título de ilustração, reproduzimos duas cartas escritas para outra personagem secundária, a Srta. Stapleton/Vandeleur, que atraiu a atenção dos alunos pela revelação, no desfecho, de que apanhava do marido. No texto lido, publicado no início do século XX, a cena de violência não é problematizada e é apenas mais um elemento do novelo a ser deslindado. Entretanto, os leitores jovens do século XXI o leem a partir dos valores de seu tempo (e de sua experiência). Interessa-nos destacar que uma das cartas foi escrita por um leitor e gostaríamos de acreditar que o fato de pedir desculpas à personagem seja um indício da assunção, talvez não consciente, da opressão estrutural do machismo: 
Querida Sra. Stapleton,

Sinto lhe informar que o corpo do seu ex-marido [não foi encontrado], você não tem culpa porque ele fez isso com você, te assustou, apavorou etc. Espero que esteja bem, me simpatizei com você desde que ouvi falar de você.

Parece ser uma mulher linda e forte, espero que você e Henry se reconciliem, formariam um ótimo casal, não vejo a hora de ver você feliz e saudável.

Melhoras. (Diário da leitora M.E.C.)

Cara Srta. Vandeleur,

Fiquei sabendo sobre o que seu ex-marido fez com sir Henry e sir Charles e também fiquei sabendo o que ele fazia com a senhorita. Peço desculpas por tudo que aconteceu mas a senhorita é bem forte e acho que agora irá ficar mais feliz ainda sem a pressão que era imposta sobre a senhorita. Novamente digo lamento muito pelo que aconteceu, então para a descontração lhe convido para ir ao teatro comigo às 20 horas. Se a senhorita tiver interesse responda esse telegrama. Um grande abraço. (Diário do leitor F.)

\subsection{O leitante (lectant) - $O$ intelecto que lê}

Se o lido $(l u)$ apreende o texto a partir de si mesmo, colocando-se no interior das cenas, o leitante é a instância que o faz a partir do projeto de dizer do autor, ou seja, está mais próximo das solicitações da obra. O leitante se lembra de que o texto é uma construção, suspendendo sua leitura imersiva e automatizada (seja por uma exigência do texto, seja por uma decisão deliberada) para mobilizar recursos intelectuais (além dos afetivos) para abordar o texto. Picard (1986) a caracteriza como a dimensão da secundaridade crítica que se interessa pela complexidade da obra e dela extrai prazer. O caráter secundário se explica pela necessidade de um recuo crítico para interpretar o texto e também pelo papel que desempenha a aprendizagem específica de um protocolo de leitura distanciada que se coaduna com a leitura do especialista. Podemos ver a dimensão do leitante como opressiva e limitadora da criatividade dos leitores singulares; ou podemos vê-la um feixe de ferramentas que podem diversificar e adensar as leituras.

Jouve (1992) destaca que para o leitante o personagem é instrumento de um duplo projeto, narrativo e semântico. Assim, desdobra o leitante em jogador (lectant jouant), aquele que procura desvendar a estrutura narrativa do texto e, acrescentemos, antecipa eventos e se preocupa com a articulação ente forma e efeito; e intérprete (lectant interprétant), aquele que busca o sentido global e, acrescentemos, simbólico da obra, associando-a também eventualmente a outros textos e ao contexto. Os exemplos abaixo pretendem dar conta de ilustrar tais categorias e foram escolhidos por tratarem de um aspecto recorrente: a mediação narrativa.

Sobre Édipo, os leitores destacam a peculiaridade do narrador, poroso ao ponto de vista do protagonista. Alguns relatam seu estranhamento na leitura individual; outros apontam para a descoberta do recurso na discussão em sala; outros ainda fizeram a observação antes mesmo do compartilhamento, pois transferiram para esta experiência de leitura os saberes construídos no ano 
anterior, durante a leitura de outra narrativa que também usava a estratégia do discurso indireto livre: "Eu não tinha percebido que o narrador estava dentro da cabeça de Édipo." (Diário da leitora A.B.); "Também gostei muito do narrador ele é bem diferente dos narradores dos livros comuns pois ele parece muito um personagem mas ele na verdade não é ele é muito participativo.”(Diário do leitor P.A.); "Nos primeiros capítulos o que mais estranhei foi a narração, o narrador parecia observador e personagem ao mesmo tempo, às vezes ele até falava por Édipo". (Diário da leitora J.); "O narrador foi algo que gostei no livro, ele fala (narra) como fosse o Édipo, isso é muito interessante, porque tínhamos que ficar pensando, 'É o narrador ou o Édipo?' Pelo menos eu ficava assim”. (Diário da leitora La.) Eu também descobri na discussão que o narrador do livro é como o de Comandante
Hussi, parece que tem uma câmera na cabeça de Édipo e por isso em algumas horas
é o narrador que fala a opinião dele ou o que está sentindo. E também descobri que o
narrador a todo momento quer que sintamos pena dele (...). Pelo menos eu senti.
(Diário da leitora M.E.O.)

Eu gostei muito dessa leitura, pois o jeito que o narrador conta a história é tão bom quanto Comandante Hussi; os contos passam na mente do protagonista, e com isso, o leitor descobre os fatos junto com o personagem principal. Acho que por esse fato, me deu mais vontade de ler. (Diário da leitora M.)

É interessante observar as diferentes maneiras com que cada leitor procura dar conta da ideia do discurso indireto livre (a nomenclatura não foi usada em sala), empregando um vocabulário próprio que revela apropriação singular e reflexão crítica da leitura partilhada. Os exemplos mostram ao mesmo tempo um esforço de teorização (na explicação sobre o narrador), crítica (na avaliação dos efeitos de sentido provocados por esse recurso e na comparação com outra narrativa) e ensaio (na expressão da reação subjetiva ao texto).

O leitor jogador revelado acima se repete nas observações sobre a mediação narrativa de $O$ cão dos Baskervilles: "O livro é muito bom, as ideias de ter o Watson para filtrar o nosso ponto de vista (o que vale para a vida) dando pistas falsas é ótima!” (Diário do leitor P.); “Em uma discussão em sala percebi que somos mais espertos que o Watson pois temos a nossa visão do texto em vários ângulos, diferentemente de Watson que tem apenas uma". (Diário da leitora S.); "Sherlock deixa o Watson como uma isca para leitores, pois o Watson é muito ingênuo e muitos casos ele deixa muitas pistas importantes ser descartadas, por isso nós achamos que ele é só uma isca para nos confundir nossa cabeça”. (Diário do leitor I.) 
uns sete capítulos depois, já que o motivo de ser o narrador é que ele não entrega todas as dicas (pois é ingênuo), cria hipóteses (assim como o leitor) e dá sem querer pistas falsas, sendo uma ótima forma para dar mais suspense e reviravoltas. (Diário do leitor M.)

Watson é o narrador, pois ele é os olhos do Sherlock, ele representa pistas falsas (pois ele representa um leitor, se ele erra nós erramos também). Ah! Ele é muito ingênuo. Alguns erros do Watson que ele cometeu e eu também cometi com ele: tirar os Stapleton como suspeitos. (Diário da leitora La.)

Tem uma coisa que eu amo que no caso é a quebra de expectativa (...). Se o Holmes narrasse a gente não ia poder investigar, ter hipótese, perguntas e conclusão (método científico) porque ele é um ótimo investigador e não ia deixar nós (a turma) pensarmos junto com ele, por isso, colocaram o Watson que é desligado das coisas e não é muito esperto, assim a gente podia fazer hipóteses, investigar, perguntar e ter mais conclusão assim nós íamos nos sentir detetive e como o Watson não tem a sabedoria de Holmes ele não nos deu todas as respostas de graça e fez o mais legal que é nos dar dicas para a gente usar elas e desvendar os casos sozinho e com umas dicas de Watson. (Diário do leitor P.A.)

Novamente chamam atenção as soluções singulares encontradas para explicar (e avaliar) as estratégias narrativas, dessa vez explicitando ainda mais o papel que a estrutura de apelo do texto reservou ao leitor. Não à toa um aluno usa o vocábulo "isca" para se referir a ela; uma aluna, ao tomar distância da narrativa, consegue perceber que "errou" junto com personagem, caiu na armadilha do autor implícito. Diferentemente do lido $(l u)$, o leitante (lectant) extrai prazer da quebra da ilusão referencial, como podemos perceber em mais de um registro o destaque positivo ao papel ativo que os leitores tiveram na construção de sentidos e ao prazer promovido por uma atividade intelectual.

O reconhecimento das estratégias, às vezes, gera uma avaliação negativa acerca de seus efeitos. O leitor implicado não responde sempre da mesma maneira ao leitor implícito, e recusa o papel que lhe é sugerido:

\footnotetext{
Acho que deveria ter uma participação maior do Sherlock Holmes, assim quando o Watson fosse descobrindo as coisas houvesse uma visão melhor da situação. Acho que ficou uma visão superficial e sem noção. (Diário da leitora E.)

Outra característica da leitura desse livro que me deixou frustrado foi que as pistas deixadas (ou não) pelo assassino só são encontradas pelos personagens do livro. $\mathrm{O}$ leitor não tem um ponto de vista próprio para observar as pistas, deduzir e resolver (ou não) o crime sozinho. (Diário do leitor A.)
}

Em algumas reficcionalizações, como alteração dos desfechos e continuação da narrativa, vários leitores se utilizaram de ambas as estratégias de mediação narrativa empregadas nas obras para dar forma aos seus "textos de leitor" (ROUXEL, 2012), 
demonstrando assim que se apropriaram das leituras feitas. A relação significativa entre forma e efeito também foi observada em algumas produções não verbais, como as seguintes:

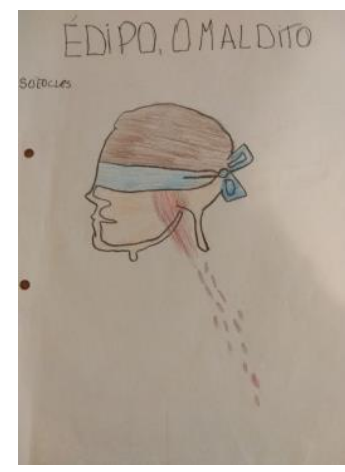

Ilustração Diário da leitora La.

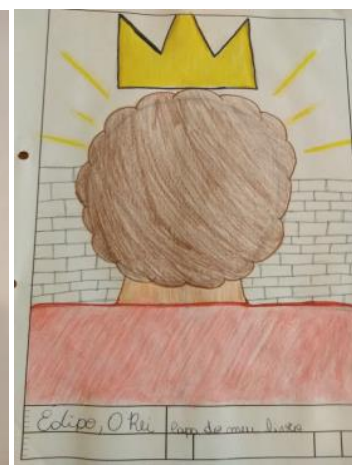

Ilustração Diário da leitora $\mathbf{R}$.

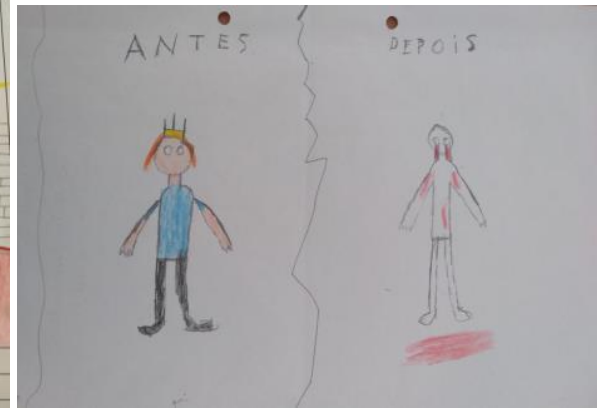

Ilustração Diário do leitor $\mathbf{E}$.

Nas três produções se sobreleva a dimensão do intérprete, ou seja, a dimensão leitora que busca coerência global e interpretação simbólica; é o leitor das camadas de sentido. Nem por isso, entretanto, a dimensão do jogador está ausente. Observamos na primeira imagem a ilustração de Édipo com o rosto duplicado, representando o desdobramento da personalidade do protagonista a partir de sua cegueira. Na segunda imagem, a leitora nos coloca exatamente no ponto de pista de Édipo (como fez o narrador), diante da muralha de Tebas, que simboliza, como veremos, todos os obstáculos a serem enfrentados pelo personagem. Notemos nos sinais gráficos a reação emotiva de Édipo. Na terceira imagem, o leitor produz visualmente a transformação exterior e interior ocorrida ao personagem.

Escolhemos os exemplos acima porque as leituras simbólicas feitas a partir da cegueira de Édipo e da presença da muralha foram as mais recorrentes. Além disso, o percurso temático empreendido pelos alunos a partir das figuras citadas (cegueiraautoconhecimento/ muralha-obstáculo; amadurecimento) nos mostram dois acercamentos distintos do investimento subjetivo no texto, um necessário, demandado pelos vazios intencionais do texto; e outro acidental, não previsto pelo projeto ficcional (JOUVE, 2013). Como exemplar do primeiro, observemos os exemplos abaixo:

Tive alguns destaques no texto como: a parte que Tirésias fala que Édipo choraria lágrimas de sangue foi com duplo sentido e me deixou tocada. Também teve a parte que Édipo de assemelha a Tirésias, pois Tirésias é cego e conseguiu ver tudo que todos não viam, então Édipo furou os olhos, pois a verdade estava toda na cara dele e ele não percebeu. (Diário da leitora M.Ed.) 
O que me deixou um pouco surpresa foi quando aquele cego falou que Édipo iria "chorar sangue", e eu nunca imaginaria que ele iria furar os próprios olhos e o jeito poético foi, quando ele enxergava ele não se via por dentro, mas depois que parou de enxergar, ele se via por dentro. (Diário da leitora M.E.C.)

Édipo cumpriu sua promessa, ao saber que ele era o vilão da história, furou os olhos e, com isso, ficou cego. Fazendo-se algo de dentro para fora, porque ele estava cego por dentro, ele não se conhecia, e ao se cegar, Édipo aceita o "assassino" que há dentro de si. Isso pode o mostrar mais humilde. (Diário da leitora M.)

Duas contribuições que eu amei e achei lindas, foram a do T. e a da M. Ed.. A M.Ed. falou: "O furar os olhos de Édipo além de se punir, é ele ganhar percepção das coisas, é como se fosse "enxergar" o que com os olhos dele não conseguem ver". E o que o T. falou foi "Jocasta também é uma "espécie de cega, porque ela não quer enxergar a verdade, ela não acredita nos oráculo." (...) Édipo foi mais um maravilhoso livro, que mudo meu posicionamento como "Hussi", meus olhos de ver o mundo e me ajudou a repensar minhas atitudes... (Diário do leitor D.M.)

Podemos observar como as dimensões do jogador e do intérprete estão entrelaçadas, pois é a percepção de um deslizamento de sentido (ou como uma leitora afirma, "o poético") da expressão "chorar lágrimas de sangue" que os leva a uma interpretação global e simbólica da narrativa. Observemos também como os alunos vão seguindo as pistas semânticas de cada recorrência da ideia de cegueira, construindo uma verdadeira teia de metáforas a partir de Tirésias, Édipo e até mesmo Jocasta para se referirem ao autoengano/autoconhecimento, humildade/ arrogância; culpa - dos personagens e de si mesmos. Gostaríamos de destacar ainda que a expressão "olhos de ver" foi retirada do livro Comandante Hussi, citado pelo aluno, mais uma vez apontando para o papel da escola na construção das bibliotecas interiores dos leitores. Por fim, é relevante sinalizar o fato de que a complexidade dessas interpretações não parte de um roteiro pré-programado pela professora. O último registro nos deixa entrever como se dá o processo de construção de sentidos a partir do compartilhamento. O comentário de outra aluna também é revelador nesse sentido, ilustrando o que Picard (1986) quis dizer com modos secundários de ler:

No começo do livro já imaginei que o problema todo era por culpa de Édipo, mas nem registrei no papel porque não tinha conseguido organizar na mente. $E$ a discussão me ajudou muito, graças a ela entendi o porquê de ser culpa dele (Em parte, não foi totalmente culpa dele). (Diário da leitora M.E.O.)

Os registros a seguir exemplificam o segundo tipo de investimento subjetivo, a que Jouve (2013) chama acidental: 
Achei o começo de Édipo, semelhante todos os livros lidos no sexto ano (Hitomi, Comandante Hussi e $\mathrm{O}$ mágico de Oz). Pois esses livros falam de amadurecimento, e quando Édipo passou pelo palácio de Tebas, ele amadureceu, pois teve filhos e virou rei, com isso, ele governava, ajudava, resolvia os problemas pelo seu povo. (Diário da leitora M.)

No sexto ano, todos os livros que li tinham a ver com maturidade. No Édipo, também percebi isso. Mas cada personagem agiu de uma forma diferente diante dessa mudança, Hitomi reagiu bem, Hussi superou, Dorothy voltou para o seu mundinho (evoluiu pouco) e Édipo, sem saber lidar muito bem com isso, arrancou os olhos. (...) Ao longo de sua jornada, Édipo enfrentou problemas. Assim como na via das pessoas, só que existem umas que superam os problemas; e outras que não superam. Não é só eu que passo por problemas de vários tipos, todas as pessoas passam por isso. E os problemas também nos ajudam a amadurecer. Do que adiantaria ter uma vida fácil sem nenhuma dificuldade? O que aprenderíamos? Além de não ter graça nenhuma em viver assim. (Diário da leitora B.)

A interpretação da muralha como um símbolo para o amadurecimento é uma leitura original para a qual os leitores buscam (E encontram!) respaldo no texto, guiados pelo desejo de coerência. Tal caráter inaudito poderia ser atribuído a uma projeção no texto de uma vivência peculiar à faixa etária dos leitores; mas os registros dão conta de nos informar que a seleção da muralha como elemento de destaque para o percurso interpretativo se deveu a uma memória textual e afetiva partilhada pelas turmas. Os relatos são exemplares de uma atividade leitora caracterizada pelos gestos de rapto, desvio do leitor, motivados por sua projeção subjetiva (PETIT, 2013). Mesmo quando leva ao erro (o que julgamos não ser o caso), a ressiginificação pessoal do texto, operando um deslocamento de seu lugar e função original, é sempre legítima no sentido do estabelecimento da relação afetiva necessária à adesão ao texto:

\footnotetext{
Queria falar sobre a muralha em Tebas. Muralha ela serve para proteger ou defender algo, lá em Tebas também servia para se proteger de outros reinos gregos, mas para Édipo não serviu para isso ela serviu para um símbolo de amadurecimento, igual a ponte de Hitomi! Antes de Édipo chegar a Tebas e governar o trono, ele era, um garoto bom. Depois do trono ele virou um garoto orgulhoso. Por essa mudança eu não gosto de Édipo, o trono enlouqueceu ele! (Diário da leitora La.)
}

\subsection{O metaleitor - O leitor que se lê}

A introdução desta nova categoria se deve à própria natureza do diário como instrumento pedagógico. Além de procurar conjugar subjetividade e análise na recepção dos textos, estimulando-as continuamente, o registro escrito obriga os alunos a desautomatizarem seu processo de leitura e operarem sobre o próprio saber. Ao serem chamados a avaliar, no final do percurso, seu diálogo com o livro, os leitores passam a refletir conscientemente sobre a sua recepção a partir não do texto em si, mas de seu processamento cognitivo. A escrita 
sobre a leitura e a posterior discussão - "falar dos livros é voltar a lê-los" (BAJOUR, 2012, p. 25) - tornam visíveis estratégias, habilidades, atitudes e por isso assumem a função de explicitação, clarificação e autoavaliação (TAUVERON, 2005). Em outras palavras, o diário e seu compartilhamento são espaços de elaboração metacognitiva que favorecem a tomada de consciência sobre como se processa a leitura, desenvolve o automonitoramento de dificuldades e ajuda a criar responsabilidade pelo próprio aprendizado - aspectos nada desprezíveis para o leitor que a escola pretende formar para além de seus muros.

As duas imagens a seguir ilustram de diferentes formas o trabalho metacognitivo estimulado pelo diário compartilhado. À esquerda, o leitor fez um mapa mental (recurso aprendido nas aulas de ciências) para sua leitura de $O$ cão dos Baskervilles. Ele o organizou em quatro categorias: informações (sobre o contexto extratextual: autor, época etc); enredo, personagens e ambientes. À direita, o leitor criou uma metáfora visual curiosa para as sessões de compartilhamento: a turma é uma "esponja" que, a cada encontro, absorve mais informações e vai inchando de tantas conexões e insights... A mancha amarela é a esponja (ou seja, a turma), as manchas azuis são as contribuições coletivas e o desenho cinza é a cadeira da professora fechando o círculo.

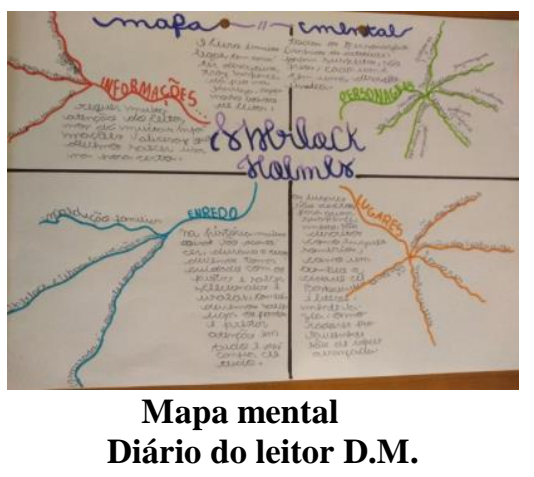

As questões mais apontadas como pontos de resistência dos textos foram o vocabulário, o registro formal, as descrições longas e a profusão de personagens (no caso de O cão dos Baskervilles) e o narrador poroso ao ponto de vista do personagem (no caso de Édipo, o maldito). Também apareceu algumas vezes o fato de os gêneros textuais serem desconhecidos ou não fazerem parte do rol dos favoritos dos leitores. Os pontos de resistência geralmente são evocados como obstáculos que foram superados, mas não necessariamente em favor de uma apreciação positiva da obra, o que não se configura um problema, já que a avaliação é resultado de um percurso de leitura. 
Nos exemplos a seguir, chama atenção como a questão do tempo se torna um critério avaliativo da leitura: "A leitura desse livro foi muito interessante e difícil a ponto de se você perder um detalhe a leitura fica muito mais difícil e se alguém te der um spoiler perde meio a graça, mas tirando esse fato, e a leitura ser muito demorada a leitura é muito fascinante”. (Diário do leitor J.P. - grifos nossos); “Achei a história ótima cheia de mistérios, intrigas e plot twists (mudança repentina e muito marcante), porém tudo que é bom vai rápido e Édipo não é diferente”. (Diário do leitor P.J. - grifos nossos); "Minha leitura foi prazerosa e rápida porque me "conectei" muito com o livro. As discussões me deixavam curiosa para saber o enredo, então quando eu chegava em casa lia tudo muito rápido. As duas partes do livro, li em um dia só”. (Diário da leitora B. - grifos nossos); "Analisei minha leitura e posso dizer que o início da história foi um pouco chato e isso atrasou a leitura. Mas com o tempo a investigação ficou mais atrativa, envolvente, divertida, com tudo isso, não senti dificuldade fora essa, a leitura foi melhorando sozinha”. (Diário do leitor D.A. - grifos nossos)

Gostei muito de ler Sherlock Holmes! O livro é muito bom, mas na minha opinião a leitura dele é bem demorada. Acho que é porque mesmo o livro sendo pequeno, as letras são minúsculas e, por ser um livro antigo, e também uma narrativa policial, ele contém um vocabulário um tanto diferente do nosso e nós temos que ler com bastante cuidado, para não deixar nenhuma pista escapar. Não foi difícil de ler, mas também não foi a leitura mais fácil que eu já fiz. O bom é que com o tempo, nós vamos nos acostumando com o vocabulário, assim não fica difícil de entender o livro, a história. (Diário da leitora M.E.P. - grifos nossos)

Apesar de a rapidez da leitura ser assimilada prontamente como um elemento positivo, relacionado à fluidez e à imersão no mundo fabulado (e é interessante que os leitores discordam quanto a que obras são mais rápidas de ler), a lentidão não é de todo desvalorizada. Remetendo ao obstáculo e à desautomatização da leitura - "Demorada, porque a escrita sendo um pouco diferente, eu tinha que pensar e pensar demora (muito!).” (Diário da leitora S.) -, o demorar-se no livro acaba por revelar o prazer conquistado pela paciência e pelo esforço consciente de concentração e superação das dificuldades, que certamente só são possíveis no contexto de criação de espaço e tempo na escola e na vida do aluno para uma rotina de leitura, como mostram os registros abaixo:

No início da minha leitura do Sherlock Holmes, eu achei o livro chato. Era um livro em que os personagens falavam muito formalmente. $\mathrm{E}$ eu realmente me lembro da parte em que o Dr. Mortimer começou a contar a lenda do cão, e eu estar odiando aquele livro. Mas nos primeiros capítulos que tive que ler sozinha, eu deixei três dias antes da entrega, então não consegui me envolver com a história. Depois desses três capítulos difíceis, comecei a ler o livro com antecedência e me envolvi mais com a 
história. E comecei a gostar dela, também. Foi uma leitura prazerosa, depois de um tempo. (Diário da leitora B. - grifos nossos)

Eu gostei muito do livro porque cada vez que você lia você sentia mais vontade ainda de ler, mas vou admitir ainda com esse aspecto do livro sinto que se não fosse a turma para discutir sobre o livro, sinto que se eu tivesse lendo esse livro sozinho iria demorar uns dois meses par terminar de ler, pois quando estou discutindo sobre o livro com alguém isso me dá inspiração para continuar a ler. (Diário do leitor W.L- grifos nossos)

Os últimos excertos insinuam diversas outras questões interessantes. Além de reforçar o papel da construção coletiva e da valorização da intersubjetividade na formação leitora, os trechos apontam para o uso produtivo de uma metalinguagem aprendida fora da sala de aula, mas que a ela é incorporada (spoiler, plot twist) e para importância da postura de disponibilidade do leitor diante do texto para aprender com ele, como advoga Margaret Meek (1988): "A leitura foi melhorando sozinha" (Diário do leitor D.A.); "Nós vamos nos acostumando" (Diário da leitora M.E.P.); "Superei as dificuldades lendo mesmo porque, a partir do momento que você se acostuma, aquilo passa a não ser mais uma dificuldade." (Diário da leitora L.)

Outras estratégias comuns para o enfrentamento dos obstáculos de leitura, além do recurso à professora e aos colegas, foram o recurso consciente à visualização - "Eu quando lia imaginava palavras semelhantes ou o que poderia ser, também me ajudava vendo, na minha mente, o que ele falaria, o tom, imaginava a cena." (Diário da leitora A.B.) - e a releitura, confirmando a proposição de Jouve (2002) de que esta é não só desejável como necessária, dado que há certas conexões que só são percebidas na segunda leitura: "Eu pensava que ia ser um livro difícil de entender e por causa disso eu estava desanimado para ler, mas eu ficava relendo, relendo até eu entender e quando eu começava a entender eu ficava feliz, porque o livro não era fácil de entender". (Diário do leitor G.) "A leitura foi demorada e em geral um pouco difícil pois tive que ficar toda hora voltando atrás no texto para tentar raciocinar o que ia acontecer, mas essa dificuldade/ atraso tem que acontecer para que o texto flua como uma narrativa policial”. (Diário do leitor J.)

Os alunos começam a perceber uma nova forma de gratificação para além do envolvimento com o tema e o enredo - "Todo mistério do livro me trouxe muita curiosidade e uma vontade imensa de entender." (Diário da leitora M.E.O.) - e acabam transformando as narrativas de investigação que leram (e seu caráter lúdico) em metáforas de seus processos de leitura, como podemos perceber na escolha vocabular: "Eu tinha que ficar decifrando o 
código e reler muito o livro." (Diário da leitora N. - grifos nossos); "Você tem que ler mais de uma vez para entender toda a história, diferente dos outros que a gente leu esse deixa muitas pistas e pensamos uma coisa e depois você lê e percebe que é totalmente diferente (quebra de expectativa)." (Diário do leitor P.A. - grifos nossos); "Nos capítulos seguintes eu comecei a criar diversas hipóteses sobre os capítulos que iriam seguir e sobre as conclusões que seguiriam a ter seu xeque-mate na mente do leitor." (Diário do leitor F. - grifos nossos); "O livro é difícil porque às vezes tinham pistas escondidas, frases dúbias e isso tornava o livro um quebra-cabeça." (Diário da leitora M.E. - grifos nossos)

Mais interessante ainda é perceber a metáfora no espelhamento dos leitores nas narrativas, atestando sua implicação na leitura: "O meu olhar era como o olhar de Watson, não conseguia enxergar nenhum ponto de vista a não ser o dele." (Diário da leitora M.E.T.); "No começo do livro achei tudo muito cofuso, meio sem rumo (igual ao Édipo) acho que a narrativa queria que o leitor se sentisse igual ao personagem.” (Diário da leitora M.E.C. grifos da leitora)

\section{Palavras finais}

Se concordamos com Picard (1986) e Jouve (1992) que durante a leitura diversas instâncias (física, emotiva/psíquica, cognitiva/ intelectual) interferem num jogo complexo de participação e distanciamento, é necessário, entretanto, questionar (sobretudo na escola) a hierarquização presente em seus quadros teóricos, já que ambos deixam claro que a leitura crítica não é apenas uma possibilidade, mas uma exigência que permitiria o prazer estético per se, próprio dos happy few.

Assim, as implicações das contribuições dos autores para a reflexão didáticopedagógica nos são muito caras: consideramos suficientemente a materialidade do livro e do ato de ler como componentes importantes do processamento leitor e do estabelecimento de relações afetivas com o mundo letrado? Convocamos psique e afetos para a leitura e para a convivência diária, fazendo da sala de aula o espaço do encontro intersubjetivo e singular de uma comunidade de leitores que também é uma comunidade de aprendizagem (HOOKS, 2017)? Estimulamos o distanciamento crítico como forma de instrumentalizar os alunos para lerem melhor fora da escola, com liberdade e autonomia, povoando o mundo e interferindo nele com suas próprias palavras? 
Nesse sentido, acreditamos que os registros escolhidos para ilustrar os diferentes modos de ler, embora sejam exemplares de cada categoria, comportam também elementos suficientes para percebermos como a implicação subjetiva move todo o percurso leitor, assim como o distanciamento crítico e a sedução da análise não estão ausentes das manifestações emotivas. O diário é um espaço privilegiado para perceber esse vai e vem dialético justamente porque os alunos são convidados a narrar seu processamento de leitura e a registrar de forma criativa suas interferências no texto, sendo cada interferência reveladora de um esforço contínuo de elaboração semântica que exige permanente ação (meta) cognitiva e afetiva.

Os registros dos jovens leitores mostram ainda que o prazer de ler não se reduz ao expediente simplista da liberdade de escolha - e sempre nos perguntamos como se dá a liberdade de escolha quando esta se restringe a uma oferta específica, que tem a ver com o lugar socioeconômico e cultural habitado pelos indivíduos. O prazer de ler, aqui, não está atrelado ao mero espontaneísmo, mas a uma construção que, não ignorando a subjetividade leitora (antes a estimulando), torna-se ponte para a descoberta de caminhos interpretativos inaugurais sobre os textos, o mundo, nós mesmos.

\section{Referências}

BAJOUR, Cecilia (2012). Ouvir nas entrelinhas. O valor da escuta nas práticas de leitura. São Paulo: Pulo do Gato.

COMPAGNON, Antoine. O demônio da teoria: literatura e senso comum. Belo Horizonte: Editora da UFMG, 2001.

DAUNAY, Bertrand. La "lecture littéraire": les risques d'une mystification. Recherches, Lille, n.30, p.29-59, 1999.

DAVIDSON, Marie Thérèse. Édipo, o maldito. Tradução Heitor Ferraz Mello. São Paulo: SM, 2006.

DOYLE, Conan. O cão dos Baskervilles. Tradução Antonio Carlos Vilela. São Paulo: Melhoramentos, 2009.

DUFAYS, JEAN-Louis. Sujet lecteur et lecture littéraire: quelles modélisations pour quels enjeux ? Recherches \& Travaux, Grenoble, n.83, p.77-88, dez., 2013.

HOOKS, Bell. Ensinando a transgredir. A educação como prática da liberdade. São Paulo: Martins Fontes, 2017.

ISER, Wolfgang (1996). O ato de leitura. Tradução de Johannes Kretschmer. São Paulo: Editora 34. 
JOUVE, Vincent. Pour une analyse de l'effet-personnage. In: Littérature, n. 85, p. 103-11, fev., 1992.

. A leitura. Tradução Brigitte Hervot. São Paulo: Editora UNESP, 2002.

A leitura como retorno de si: sobre o interesse pedagógico das leituras subjetivas. In:REZENDE, Neide Luzia et al. (Org.) Leitura subjetiva e ensino de literatura. São Paulo: Alameda, 2013, p.53-65.

LANGLADE, Gérard. Activité fictionnalisante du lecteur et dispositif de l'imaginaire. Figura, Montréal, n. 20, p. 45-65, 2008.

MEEK, Margaret. How texts teach what readers learn. South Woodchester: The Timble Press, 1988.

PETIT, Michèle. Leitura: do espaço íntimo ao espaço público.São Paulo: Editora 34, 2013.

PICARD, Michel. La lecture comme jeu. Paris: Les éditions de minuit, 1986.

ROUXEL, Annie. Práticas de leitura: quais rumos para favorecer a expressão do sujeito leitor? Cadernos de Pesquisa [online], v.42, n.145, p.272-283, jan./abr., 2012.

TAUVERON, Catherine. Que veut dire évaluer la lecture littéraire? Cas d'élèves en difficulté de lecture. Revue Repères, Lyon, v.1, n. 31, p.73-112, 2005.

VIBERT, Anne. Explicar um texto literário: o que a pesquisa em didática da literatura pode fazer para a renovação e a diversificação das práticas. Revista Letras Raras, v.3, n. 1, Campina Grande, p. 199-222, 2014. 